\title{
Local responses to a forest park in western Uganda: alternate narratives on fortress conservation
}

\author{
Joel HARTter and A b RAHAM Goldman
}

\begin{abstract}
Most research on attitudes to parks in subSaharan Africa has been in savannah regions and areas of low population density. Expulsion, exclusion and the imposition of external control are dominant themes, resulting in negative responses to parks, particularly those that represent hard-edged so-called fortress conservation. Our research in the densely populated area around a mid altitude forest park in western Uganda found an alternate narrative in which, despite its hard-edged fortress features, most people view Kibale National Park favourably. Based on a geographically random sample in two agricultural areas neighbouring the Park, our results indicate that most households felt they benefit from the Park and only a small proportion cited negative impacts. Rather than direct economic returns, the benefits most commonly noted by respondents can be characterized as ecosystem services. Most individual respondents and a large majority of the local political leaders said that the Park should continue to exist. Crop raiding by animals from the Park is a problem in some locations but resource restrictions and expulsion were not widely cited by our respondents. The fact that the large majority of residents migrated to the area after the Park was established may be an important explanatory factor for these responses, and this is also likely to be the case for many other mid altitude tropical forest parks, the demographic and land-use histories of which differ from those around many savannah parks.
\end{abstract}

Keywords Fortress conservation, Kibale National Park, protected area, sub-Saharan Africa, tropical forests, Uganda

\section{Introduction}

$\mathrm{M}$ uch social science literature has been highly critical of the negative social impacts of parks and protected areas, particularly the population displacements that often accompanied park creation and the exclusions and restrictions embedded in park policy. These have led to the view that parks have helped generate or perpetuate poverty and may have caused permanent hostility among those they affect

Joel HARTter (Corresponding author) Department of Geography, University of New Hampshire, 102 Huddleston Hall 73 Main Street, Durham, New Hampshire 03824, USA. E-mail joel.hartter@unh.edu

Aвraham Goldman Department of Geography, University of Florida, Gainesville, Florida, USA

Received 26 August 2009. Revision requested 8 October 2009.

Accepted 16 December 2009.
(Neumann, 1998; Brockington, 2002; Chatty \& Colchester, 2002; Igoe, 2004b; Brockington \& Igoe, 2006; Cernea \& Schmidt-Soltau, 2006; West et al., 2006; Büscher \& Wolmer, 2007; Shetler, 2007; Roe, 2008; Schmidt-Soltau, 2009).

A number of other social science studies, which are based on sample surveys of people currently living near parks rather than reconstructions of park histories, find a complex mixture of positive and negative attitudes (Infield, 1988; Newmark et al., 1993; Gillingham \& Lee, 1999, 2003; Gadd, 2005; Robertson \& Lawes, 2005; Lepp \& Holland, 2006; Anthony, 2007). Crop losses to animals, and the common lack of compensation for such losses, are usually cited as the main negative impact of parks and the principal reason for discontent over their presence. Positive responses are mainly based on economic returns from parks, which may accrue to households from employment, revenue sharing or other economic opportunities.

Much of the variation in findings may be accounted for by the different populations on which the studies focus. The more critical literature concerns itself mainly with the groups most severely affected by the historic experience of park creation, whereas contemporary survey studies mainly deal with people currently living in the vicinity of parks, and the overlap between these two groups is often limited.

In addition, the great majority of studies are based on savannah (including savannah woodland) environments, which is unsurprising given that most of sub-Saharan Africa's non-desert land area, and most of the area that has been included in parks and other protected areas, is in savannah and savannah woodland regions, especially in eastern and southern Africa (Burgess et al., 2007). Moreover, most studies have been in areas of low or moderate human population density, even some of the relatively few studies of forest parks (Robertson \& Lawes, 2005). In contrast, mid altitude and higher altitude forest areas often have the potential to support dense agricultural populations because of favourable rainfall and soil conditions (e.g. the mid altitude parks in Uganda, Bwindi, Mt Elgon and Kibale, are all surrounded by densely populated agricultural areas). Parks and protected areas in these environments are generally much smaller in area and are fewer and even more threatened than savannah parks. However, these parks protect increasingly scarce species and habitat, including mountain gorillas Gorilla beringei and other primates, and a range of bird species, trees and other forest flora (Struhsaker, 1997; Terborgh \& van Schaik, 2002).

Much of the literature on the impacts of, and responses to, parks by local people suggests that the attitudes to parks 
are likely to vary with differing balances of benefit and harm from the park among households, and these in turn are likely to vary among social and economic groups. Among the main factors that have been suggested to affect people's assessments are a personal or family history of expulsion or restriction by the park, losses and risks experienced because of park animals, and a household's access to financial benefits from a park. These in turn may vary with such features as wealth, gender, location, and degree of reliance on agriculture (Fiallo \& Jacobsen, 1995; NaughtonTreves, 1997; Neumann, 1998; Emerton, 1999; Hill, 2000; Brockington, 2002; Brockington \& Igoe, 2006; Baral \& Heinen, 2007). In particular, we would expect that:

(1) poorer households are more likely to have negative evaluations of parks than wealthier households since the former are less able to manage or cope with the risks or to realize financial benefits from a park;

(2) those whose livelihoods are more dependent on agriculture, as well as those who are more intensive cultivators, are likely to have more negative attitudes because of the greater risks and potential losses they face from park animals;

(3) women are more likely to have negative attitudes because their incomes are often more dependent on food crop production, which is likely to be highly susceptible to damage from park animals, while men are more likely to focus on income-earning crops, which may be less vulnerable to animal damage;

(4) those located closer to the park boundary are likely to have more negative attitudes than those further away as the former are more exposed to crop raiding by park animals;

(5) those who themselves or whose families were expelled from the park, or who have been excluded from use of park land or other resources, are more likely to have negative attitudes to the park than those who have not had such experiences.

We explore and discuss these expectations in relation to the results from our surveys conducted around Kibale National Park in western Uganda.

\section{Study area}

The $795 \mathrm{~km}^{2}$ Kibale National Park is notable for the numbers and diversity of its primates (Wrangham \& Ross, 2008) as well as its extensive floral biodiversity (Struhsaker, 1997; Fig. 1). It was established as a forest reserve in 1932 and became a National Park in 1993, at which time nearly all timber and other resource extraction, which had expanded during prior periods of Ugandan political instability, were prohibited (Struhsaker, 1997). A substantial number of people, most of whom had settled in the wildlife game corridor to the south-west of the Park during the 1970s, were forcibly evicted and resettled (Van Orsdol, 1986; Feeney, 1998; Chapman \& Lambert, 2000).
Tourism to Kibale is driven by its chimpanzees Pan troglodytes and has been increasing in recent years. Although visits (7,700 in 2008) and revenues are low compared to some Ugandan (UBOS, 2009) and other East African savannah parks (Akama \& Kieti, 2003), and have usually barely covered operating expenses, they are increasing. Park authorities expected tourist revenues in the fiscal year 2007-2008, including entry and chimpanzee tracking fees, to total UGX 1.2 billion (c. USD 800,000; C. Tumwesigye, pers. comm., 2008). Twenty percent of gate receipts (not including chimpanzee-tracking fees) are returned to some of the neighbouring communities.

Most of the area around Kibale is dominated by small farms $\left(<_{5} \mathrm{ha}\right)$, with tea estates to the north-west, and a network of low-lying forests and wetlands that are important sources of water and fuelwood to residents (Hartter, 2010). The human population around Kibale has grown rapidly since the 1950s through immigration and natural increase (>300\% during 1959-1990; Naughton-Treves, 1998). Population in the subcounties that border the Park totalled almost 240,000 in the 2002 census (UBOS, 2005). In our research areas within $5 \mathrm{~km}$ of the Park boundary (Fig. 1) estimated population densities are c. $260 \mathrm{~km}^{-2}$ to the west of the Park and $335 \mathrm{~km}^{-2}$ to the east (Hartter, 2010).

Two main ethnic groups occupy most of the land surrounding Kibale. Western regions are dominated by the Batoro, who began to settle in the area near the Park in the first few decades of the 20th century (Steinhart, 1977; Naughton-Treves, 1999; Goldman et al., 2009). Much of the area east of the Park is populated by the Bakiga, most of whom migrated to this region during the 1950 s to $1970 \mathrm{~s}$ from the densely populated and intensively cultivated areas in the south-west of Uganda (Carswell, 2007). There are also some Bakiga settlements in areas west of the Park, and the rehabilitation of tea estates around Kibale in the $1990 \mathrm{os}$ led to further immigration of Bakiga and others as tea workers (Mulley \& Unruh, 2004). In general, Bakiga are viewed locally as more intensive farmers than Batoro, with agricultural incomes more reliant on sales of maize and other food crops than most Batoro (Kirner, 2010).

The boundaries of the Park are clearly demarcated. Virtually all the people living around Kibale are officially excluded from extractive activities or land use within the Park (with very few exceptions for limited timber extraction, medicinal plant, wild coffee and firewood collection, and fishing). Although some illegal incursions for timber or hunting take place, large-scale extraction or alteration of Park habitat has not occurred since the late 1980s. Viable populations of many primate species exist and the Park canopy is intact (Struhsaker, 2005; Wrangham \& Ross, 2008; Hartter \& Southworth, 2009; Southworth et al., 2010). Crop losses to Park animals are common, especially near the Park boundary, but direct compensation for losses is forbidden under Uganda law. 


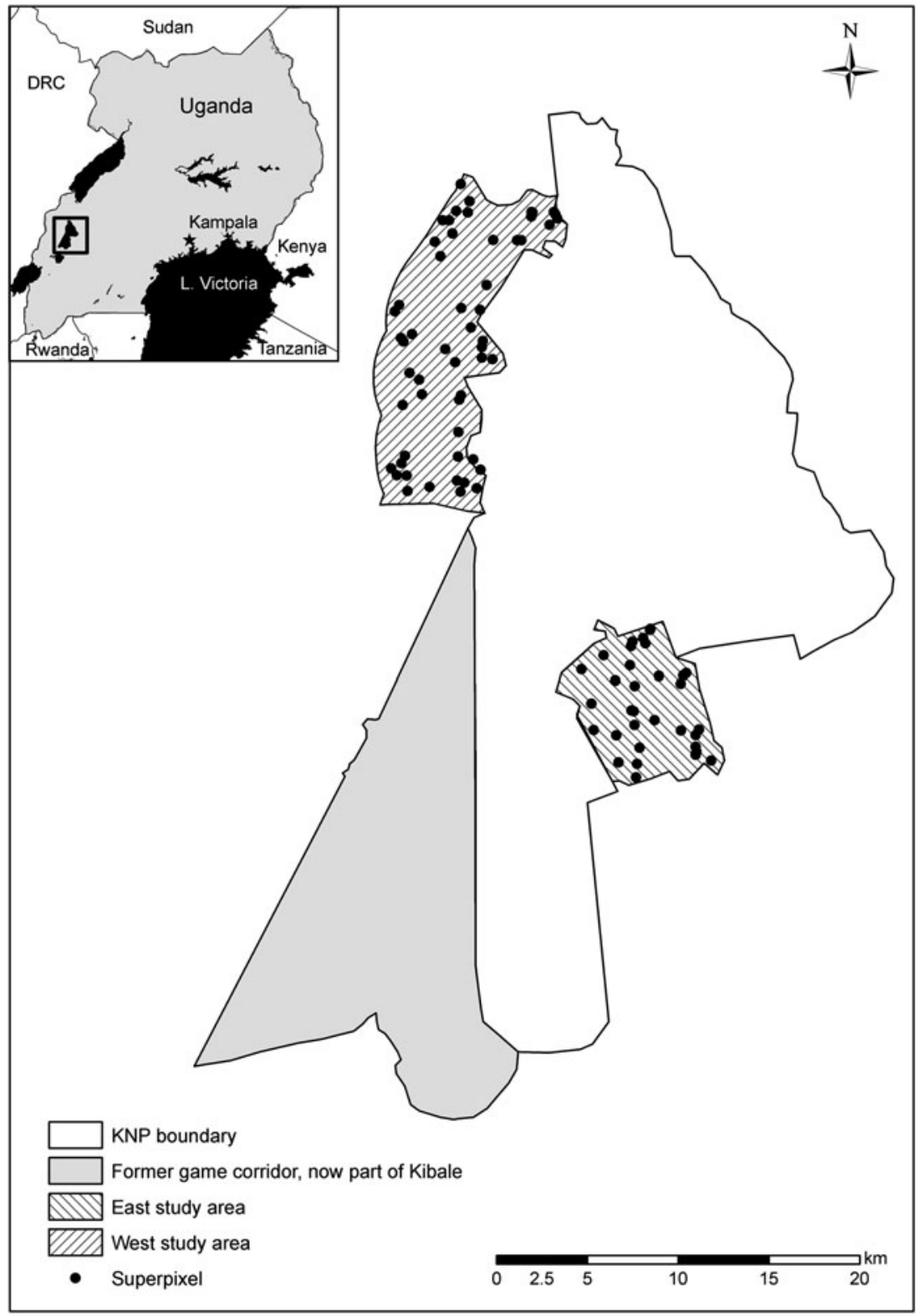

Fig. 1 Kibale National Park (KNP) in western Uganda, showing the research areas to the west and east of the Park and the sampling units (superpixels, see text for details). The rectangle on the inset indicates the location of the main figure in south-west Uganda.

\section{Methods}

We defined a 5-km perimeter around Kibale National Park as our study area and within this carried out research to the east and west (Fig. 1). These two regions differ in altitude, ethnic composition, and settlement and land use history. We then employed a geographically random sampling procedure for interdisciplinary research by randomly selecting geographical coordinates within the two regions. These points were defined as the centres of 9-ha sampling units (superpixels) that have been used for collection of social as well as land cover and biological data (Goldman et al., 2008; Hartter, 2009, 2010; Hartter \& Goldman, 2009).

Interviewees were selected in each of the superpixels for which there were individual landholders, which included 68 of the 95 superpixels (the other 27 fell within tea estates, wetlands or crater lakes). One hundred and thirty semistructured household interviews were conducted in these 68 superpixels during May-August 2006. The number of respondents selected per superpixel was proportional to the number of landholders within each area, with at least one interview conducted in each. Sixteen additional interviews were conducted with village chairmen of some of these communities (at the Local Council 1, LC1, level: an administrative unit consisting of one or a few villages under the jurisdiction of a single chairperson). Interviews were conducted in local languages (Rutoro or Rukiga) using an interpreter, or in English, with one or both of the principal researcher(s) present.

Among the issues covered were whether and in what ways respondents benefited from the Park, whether and in what ways they were harmed by the Park (both responses 
were permissible and often given) and whether they would prefer that the Park be maintained or dissolved. Although our sample was not pre-segmented, a number of social and locational groups emerged as subsamples. Table 1 shows the sample breakdown by wealth, ethnicity, gender, and location relative to the park.

Respondents' wealth levels were classified into three general categories (based on house construction, land size, head of household gender, and number and types of livestock) using agglomerative cluster analysis (Ward's method). Ethnicity (which, among other characteristics, is related to agricultural intensity), gender, and location were also distinguished in our surveys. Household locations relative to the Park were categorized as $<_{1} \mathrm{~km}, 1-3 \mathrm{~km}$

TABLE 1 A summary of the responses to the question of whether respondents (in total and by subcategory) felt that Kibale National Park (Fig. 1) has helped and/or harmed them and their households, by ethnic group, gender, wealth, distance from Park and side of Park, with sample sizes. Relationships between responses and independent variables were examined using Pearson $\chi^{2}$ tests for independence.

\begin{tabular}{|c|c|c|c|}
\hline Sample/Subsample & $\begin{array}{l}\text { (Sub)sample } \\
\mathrm{n}(\% \text { of total) }\end{array}$ & $\begin{array}{l}\text { Park has } \\
\text { helped }\end{array}$ & $\begin{array}{l}\text { Park has } \\
\text { harmed }\end{array}$ \\
\hline Total sample & 130 & $61 \%$ & $34 \%$ \\
\hline \multicolumn{4}{|l|}{ Ethnic group(s) } \\
\hline Batoro & $72(55 \%)$ & $58 \%$ & $33 \%$ \\
\hline Bakiga & $46(35 \%)$ & $67 \%$ & $35 \%$ \\
\hline Other & $12(9 \%)$ & $50 \%$ & $33 \%$ \\
\hline $\mathrm{P}$ & & 0.447 & 0.513 \\
\hline \multicolumn{4}{|l|}{ Gender } \\
\hline Male & $63(48 \%)$ & $71 \%$ & $40 \%$ \\
\hline Female & $67(52 \%)$ & $51 \%$ & $28 \%$ \\
\hline $\mathrm{P}$ & & $0.012^{*}$ & 0.119 \\
\hline $\begin{array}{l}\text { Male-headed } \\
\text { households }\end{array}$ & $102(78 \%)$ & $63 \%$ & $38 \%$ \\
\hline $\begin{array}{c}\text { Female-headed } \\
\text { households }\end{array}$ & $28(22 \%)$ & $54 \%$ & $18 \%$ \\
\hline $\mathrm{P}$ & & 0.253 & $0.046^{*}$ \\
\hline \multicolumn{4}{|l|}{ Wealth } \\
\hline Poorer & $58(45 \%)$ & $60 \%$ & $35 \%$ \\
\hline Average & $59(45 \%)$ & $61 \%$ & $36 \%$ \\
\hline Wealthier & $13(10 \%)$ & $62 \%$ & $23 \%$ \\
\hline $\mathrm{P}$ & & 0.995 & 0.682 \\
\hline \multicolumn{4}{|l|}{ Distance from Park } \\
\hline$<1 \mathrm{~km}$ & $61(47 \%)$ & $51 \%$ & $57 \%$ \\
\hline $1-3 \mathrm{~km}$ & $33(25 \%)$ & $67 \%$ & $18 \%$ \\
\hline $3-5 \mathrm{~km}$ & $36(28 \%)$ & $72 \%$ & $8 \%$ \\
\hline $\mathrm{P}$ & & $0.082^{*}$ & $0.000^{*}$ \\
\hline \multicolumn{4}{|l|}{ Side of Park } \\
\hline West & $79(61 \%)$ & $54 \%$ & $35 \%$ \\
\hline East & $51(39 \%)$ & $71 \%$ & $31 \%$ \\
\hline $\mathrm{P}$ & & $0.048^{*}$ & 0.388 \\
\hline
\end{tabular}

${ }^{\star}$ Response (e.g. 'Park has not helped') and category (e.g. male headedhouseholds) are not independent $(\mathrm{P}<0.1)$. Therefore there is a significant relationship between response and category. and $3^{-5} \mathrm{~km}$ from the Park boundary. A disproportionate number of households were in the superpixels located within $1 \mathrm{~km}$ of the Park (61 of 130), largely because (as a random outcome) one of the superpixels fell in the middle of a village centre. Relationships between responses and independent variables were examined using Pearson $\chi^{2}$ tests for independence.

\section{Results}

Table 1 summarizes responses to the question of whether respondents felt that the Park has helped and/or harmed them and their households. Sixty-one percent of respondents said the Park had helped them in one or a number of ways and $34 \%$ that they were harmed by the Park in some way $(21 \%$ indicated neither positive nor negative impacts from the Park).

Despite more intensive farming practices and greater orientation to crop agriculture amongst the Bakiga (which makes them more vulnerable to crop raiding), responses were consistent across ethnic groups. However, there was a pronounced difference between responses on the eastern and western sides of the Park. Contrary to expectations $>70 \%$ of respondents on the east side (which is almost entirely Bakiga and is more intensively cropped) said that the Park has helped compared to $54 \%$ of those on the west side (which is mainly Batoro, but also includes Bakiga residents).

Women respondents were somewhat less positive but also less negative about the Park than men (although not significantly). Fifty-one percent of women (and a comparable proportion of female-headed households) said that the Park has helped them compared to $>70 \%$ of men.

Sixty percent of respondents in each wealth category stated that the Park has helped them and c. $35 \%$ of the poorest and middle groups stated that the Park has harmed them. A smaller percentage of the wealthiest category noted harmful impacts but the small size of this subsample makes it difficult to draw confident conclusions.

In contrast to wealth, distance from the Park showed a strong gradient with respect to perceptions of both benefits and harm, consistent with expectations. A far higher percentage of respondents who live $<_{1} \mathrm{~km}$ from the Park noted harmful effects, compared to those who live $1-3 \mathrm{~km}$ and $3-5 \mathrm{~km}$ from the Park. Similarly, those closest to the Park have the lowest percentage of responses indicating that the Park has helped them. If it were not for the disproportionately high number of respondents from the area closest to the Park the total sample mean for harmful impacts would be even lower and that for helpful impacts would be even higher.

Only a small proportion of respondents who indicated that they considered the Park helpful cited any of the material benefits that other studies (Emerton, 1999; Infield \& Namara, 2001; Brown, 2002; Agrawal \& Redford, 2006) 
suggest are critical factors: revenue shared with residents, employment or infrastructure (schools, clinics, roads). Instead, a number of what can be considered ecosystem services were widely noted by respondents as the main benefits they derive from the Park's presence (Table 2).

The most frequently reported benefit, cited by $73 \%$ of respondents who noted any benefits, was that the Park improves or maintains desirable environmental conditions. Improving rainfall (both quantity and timing), helping maintain or enhance a favourable local climate (including moderation of temperature and moisture), and improving or maintaining air quality, and soil moisture and fertility were all cited. Respondents reported the widespread perception of timely and adequate rainfall and air quality that has come from, and been reinforced by, a combination of Park outreach programmes, education programmes by non-governmental organizations, radio broadcasts in partnership with the National Environment Management Authority, a foreign volunteer who worked in schools in the area in the 1990s, second-hand information and local lore. The accuracy of these climate perceptions is unclear, although rainfall records indicate some increase in annual rainfall in recent years (T. Struhsaker \& C. Chapman, unpubl. data; Hartter, 2010).

The second most commonly noted benefit (42\%) was that the Park 'confines wild animals'. This expresses a widely perceived ethno-ecological narrative that prior to the Park's establishment wild animals roamed throughout the landscape whereas, since then, wild animals are mostly confined within or close to the Park boundaries. Several

TABLE 2 Percentage and number of respondents who perceived particular benefits or negative impacts of Kibale National Park (Fig. 1).

\begin{tabular}{lrr}
\hline & $\%$ & $\mathrm{n}$ \\
\hline Perceived benefits $\left(\mathbf{n}=\mathbf{7 9}^{\mathbf{1}}\right.$ ) & 73 & 58 \\
Maintains \&/or improves environment & 42 & 33 \\
Confines animals & 14 & 11 \\
Employment & 11 & 9 \\
Education & 11 & 9 \\
Resources (e.g. wood, medicinal products) & 6 & 5 \\
Funds for government \& infrastructure & 6 & 5 \\
Tourism & 18 & 14 \\
Other & & \\
Perceived negative impacts $\left(\mathbf{n}=\mathbf{4 4}^{\mathbf{2}}\right.$ ) & 89 & 39 \\
Crop damage by animals & 11 & 5 \\
No access to resources & 2 & 1 \\
Evicted from Park & 2 & 1 \\
Higher land prices & 5 & 2 \\
Park does not help people & 9 & 4 \\
Other & & \\
\hline
\end{tabular}

${ }^{1}$ Specified by the 79 respondents who stated that the Park helps them in some way

${ }^{2}$ Specified by the 44 respondents who stated that the Park harms them in some way people expressed the belief that, in the absence of the Park, wild animals would probably to return to the areas that are now fields and homesteads.

Material benefits associated with the Park were cited considerably less often by respondents. Only $14 \%$ of respondents who noted Park benefits mentioned employment as a direct benefit, and only $11 \%$ said they 'collect resources' from within the Park (which can be done through multiple-use agreements between the Park and communities for such resources as firewood and medicines). It is possible that non-sanctioned resource collection, or purchase of non-sanctioned wood or other resources, is more widespread than reflected in these responses. Only 6\% of respondents stated that they or their household benefited in some way from tourism, and only a comparable proportion cited funds for infrastructure or government. In many cases those who do know about the revenue-sharing programme are ambivalent towards it. Often, they believe either that the funds have been squandered, the project remains unfinished or the particular benefit has little direct positive impact on them, or the meagre amount of money that does come back to the communities is not used to help those individuals who have suffered most from crop predation by Park wildlife.

Infrastructure benefits were more prominent in the survey of the $16 \mathrm{LC} 1$ chairmen: 11 of the 16 said that their zone had benefited in some way from the Park's existence (Table 3). Twenty percent of Park gate receipts are returned to neighbouring communities. Leaders also cited, more frequently than their constituents, the Park's economic benefits in stimulating employment and business. They also emphasized the importance of the Park in maintaining a favourable environment.

For the respondents who reported that they were harmed in some way by the National Park (34\% of the total sample), the predominant problem (cited by $89 \%$ of those who noted harmful effects) was crop raiding and other damage by wild animals. Over half of those citing harmful impacts live within $1 \mathrm{~km}$ of the Park boundary (57\%), whereas $<10 \%$ of those living $3 \mathrm{~km}$ or more from the Park boundary cited any harmful impact from the Park.

TABLE 3 Percentage and number of the 16 LC1 chairmen who perceived various benefits from Kibale National Park (Fig. 1).

\begin{tabular}{llr}
\hline Has the LC zone benefited from Kibale National Park? & $\%$ & $\mathrm{n}$ \\
\hline Yes & 73 & 11 \\
School classrooms/staff houses & 64 & 7 \\
Chase/scare/shoot animals & 45 & 5 \\
Maintains/improves the environment & 45 & 5 \\
Jobs for constituents & 36 & 4 \\
Increased business in village & 36 & 4 \\
Built/maintained roads & 18 & 2 \\
Built bridges & 18 & 2 \\
\hline
\end{tabular}


Only a small proportion of respondents cited expulsion and exclusion from resources as negative impacts. Eleven percent (of the 44 who cited negative impacts) noted denial of access to resources within the Park as a significant problem, and extremely small percentages of respondents cited displacement, higher land prices or getting 'no help from the Park' as problems.

Seventy-three percent of respondents felt that Kibale should be maintained as a Park, and only $9 \%$ said that they would prefer that it be abolished ( $18 \%$ were indifferent). When asked the reasons for their opinions, people again emphasized environmental benefits (53\%) and keeping animals confined within the Park $(33 \%)$ as justifications for maintaining the Park. Education, employment, generating revenue for the government and infrastructure improvements (roads, schools, clinics) were also mentioned but by substantially lower proportions of respondents. Ten percent of respondents thought that the Park should relax its strict regulation on resource harvesting. Residents also said that they expect that Park management will help poor households around the Park in the future.

\section{Discussion}

These results differ in several important respects from the expectations and findings of previous studies of people's attitudes to parks (Newmark et al., 1993; Neumann, 1998; Brockington, 2002; West et al., 2006; Adams \& Hutton, 2007): (1) Rather than hostility (Neumann, 1998; Brockington, 2002; Adams \& Hutton, 2007), a majority of respondents felt that they benefit from the Park; only about one third felt they are harmed by the Park and only c. $10 \%$ felt that the Park should be removed. (2) Crop raiding losses are the main harmful effects cited by respondents, rather than the expulsions and restrictions (historic or contemporary) noted by other studies (Edmunds, 1997; Neumann, 1998; Brockington, 1999, 2002; Cernea \& Schmidt-Soltau, 2003; Schmidt-Soltau, 2003, 2009). (3) Material benefits from the Park, either directly to individuals or to the community at large, were cited only by a few respondents, in contrast to survey findings (Gillingham \& Lee, 1999; Igoe, 2004a; Gadd, 2005; Brockington et al., 2006) in other, mostly savannah and low-density, regions. Instead, the main benefits noted are the broad environmental services of improving climate and air quality as well as 'confining wild animals'.

We also found variations from expectations for many of the household or respondent characteristics that are thought to be associated with negative assessments of parks (Gillingham \& Lee, 1999; Gadd, 2005): (1) There were no significant differences in responses among wealth categories and no indication that the poorer residents consider the Park more harmful or less beneficial than do wealthier residents. (2) Greater agricultural orientation or intensity does not seem to be associated with more negative responses to the Park. (3) There were only slight, but not significant, gender differences in responses. (4) The most important variations in responses were based on location relative to the Park, with those closer to the Park far more likely to cite harmful effects and less likely to cite benefits than those farther from the Park. (5) Resentment because of a personal or family history of expulsion from the Park was a negligible factor. Although there are households in the area that were expelled from the Park in the 1990s they comprise a small proportion of the current population and are thus unlikely to appear significantly in any random sample.

We believe that the demographic history of the area and its environmental characteristics are important in helping explain the contrast between some of our results and the findings of other studies in sub-Saharan Africa. The great majority of people currently living near Kibale are recent migrants, or descendants of migrants, who arrived in the area near the Park between the 1950s and the 1980 s (Goldman et al., 2009). The forest reserve already existed and, in contrast to many savannah parks, the current residents of the area do not have ancestral claims on the land that became Kibale National Park in the 1990s. This history helps explain the low number of respondents who cite exclusion from the Park as a major harmful effect, which is particularly noteworthy in view of the fact that $47 \%$ of total respondents live within $1 \mathrm{~km}$ of the Park boundary, an area in which residents may be expected to be most sensitive to the exclusion from the forest for resource collection. More broadly, we suggest that similar conditions and settlement histories are likely to be found in most mid altitude or higher altitude forest parks in Africa because otherwise (i.e. if there have been large numbers of long-term residents who pre-date the establishment of a forest reserve or park) those areas would not have remained forested long enough to have become forest parks.

Other explanatory factors relate to our sampling process. Most previous studies in this area were confined to locations contiguous or close to the Park boundaries, and they found greater negative assessments of the Park (Edmunds, 1997; Naughton-Treves, 1997; Lepp \& Holland, 2006). In contrast, our sample extends to $5 \mathrm{~km}$ from the Park boundary. The results would have been somewhat different had our research been limited to people who live very close to the Park. Over half of respondents living within $1 \mathrm{~km}$ of the Park said that it caused them harm, in contrast to only c. $10 \%$ of those $>_{1} \mathrm{~km}$ from the Park. This indicates that the main negative impacts of a park surrounded by a large agricultural population decline rapidly with distance.

Although it is useful to identify the responses and opinions of those who live next to a park, a fuller understanding of responses is afforded by a sample such as ours that includes respondents who live further from, but still relatively close to, the park boundary. A recent study of population change near protected areas used a $10-\mathrm{km}$ zone around parks 
(Wittemyer et al., 2008), and there are cases, particularly in savannah regions with long-distance migratory animal populations, where even $10 \mathrm{~km}$ might be considered too close to assess park impacts and responses fully.

A feature that did not emerge as a strong explanatory factor for favourable attitudes to the Park was the revenuesharing programme mandated by the 1996 Wildlife Statute. Twenty percent of entrance fees (which represent c. 30\% of total Park income, the remainder coming mainly from chimpanzee-tracking fees) is dispersed to communities in neighbouring parishes through this programme. The money has been used for community infrastructure development (improvements in schools, roads, etc.) or trenches along the Park boundary (see below). Although the projects funded by the revenue-sharing programme are not negligible, they seem not to have made a widespread impression on most of the people in the area.

Other aspects of Uganda Wildlife Authority's community outreach may be more important and both the Authority and other bodies may have helped reinforce the widespread conviction that the Park and forest help improve the region's climate and air quality. Respondents in our survey areas do not seem to be unique in these perceptions. Mugisha (2002), using a broad sample of respondents living near several Ugandan parks, and Solomon (2007), who studied groups living near the southern boundary of Kibale, found similar perceptions. These findings suggest that environmental education and community outreach programmes that help foster a sense of the environmental services of forests could play a larger role than generally recognized in generating support for protected areas.

Many of our respondents who voiced concern about crop raiding said that their objection was not to the Park itself but to the animals that leave the Park and attack their fields. What they want is not removal of the Park but a less permeable barrier between the Park and the surrounding human landscape. In recent years there has been a confluence between these perceptions and Uganda Wildlife Authority policy initiatives. Since 2007 the Authority has tried to persuade communities bordering the Park to use their revenuesharing funds to construct or extend trenches along the Park boundaries (Kajubu, 2008). These are mainly intended to prevent elephants Loxodonta africana from leaving the Park. Although trenches do not necessarily stop primates (and when interrupted by roads or other gaps, they do not provide complete protection from elephants), people reported to us that the effort has been relatively successful.

Contrary to the critical studies of parks that cite pervasive negative impacts and attitudes, particularly for hard-edged so-called fortress conservation parks, we found widespread positive attitudes to Kibale National Park and fewer negative assessments than expected. Moreover, although crop losses to animals are a serious concern, exclusion from the Park's land or resources is not seen as an important negative impact by most people in the area. Also, contrary to expectations, these responses are not related to wealth, gender or agricultural intensity. Instead, location relative to the Park boundary is the main variable that differentiates responses to the Park. Negative responses are considerably more prevalent and positive assessments are less common among those people within $1 \mathrm{~km}$ of the Park than amongst those 1-5 $\mathrm{km}$ from the Park boundary.

Rather than economic and material benefits, the main perceived benefits of the Park involved environmental services, the common beliefs that the forest improved rainfall and air quality and that it provided a habitat for wild fauna that might otherwise be dispersed across the human agricultural landscape. We believe that there are four important, broader implications.

Firstly, perceptions of generalized environmental benefits of forests and other undomesticated areas may be more widespread and significant than generally appreciated. With respect to the link between forest and climate, our results suggest the influence and benefits of environmental education programmes, especially in areas near parks but also in other parts of the country, enhance a sense of such environmental services (Hartter, 2010).

Secondly, the sharp distance-related decline in reports of harmful impacts from Kibale National Park helps to verify that those living closest to a park bear a disproportionate share of the negative impacts. Mitigation and compensation programmes should focus on these areas and the people in them. In particular, mitigation mechanisms that enhance effective barriers between people and wildlife (such as those currently being promoted by the Uganda Wildlife Authority) are likely to be particularly appropriate.

Thirdly, the impacts of, and responses to, parks are likely to vary across the surrounding landscapes. A geographically diverse research framework, the specifics of which will vary with the nature of the human landscape around the Park, is likely to yield more nuanced results than research confined to one or two communities or to areas immediately contiguous to the Park's boundary.

Fourthly, with respect to broader debates about the negative impacts of protected areas, we believe that our findings do not contradict the burdens and injustices imposed on households and communities who were victims of expulsion or maltreatment during the course of the history of a park. The majority of the population around Kibale National Park were not victims of expulsion, having immigrated to the area after the Park was created. Although some still bear the burden of crop losses to Park animals (as well as the opportunity costs of time spent guarding fields), most of those who now live near the Park cannot be said to have been impoverished by its creation or presence. We believe that the responses of the current population are of considerable relevance to the future sustainability of parks as well as to the objectives of enhancing the benefits and 
reducing the costs that parks can impose on people in surrounding landscapes.

\section{Acknowledgements}

We gratefully acknowledge the financial support of the US National Science Foundation, award number 0352008, University of Florida Center for African Studies David L. Niddrie Memorial Scholarship and a Working Forests in the Tropics Field Research grant. Valuable contributions in the field were made by our field assistants Erimosi Agaba and Peace Mwesigwa. In addition, Makerere University Biological Field Station, Uganda Wildlife Authority, Uganda Council for Science and Technology and many local officials provided useful assistance and granted permission for the research. Finally, we wish to thank the many farmers who were willing to tolerate our questions and tell us about their lives.

\section{References}

Adams, W.M. \& Hutton, J. (2007) Parks, people and poverty: political ecology and biodiversity and conservation. Conservation and Society, 5, 147-183.

Agrawal, A. \& Redford, K. (2006) Poverty, Development, and Biodiversity Conservation: Shooting in the Dark? Working paper no. 26. Wildlife Conservation Society, New York, USA.

Акама, J.S. \& Kiеті, D.M. (2003) Measuring satisfaction with Kenya's wildlife safari: a case study of Tsavo West National Park. Tourism Management, 24, 73-81.

Anthony, B. (2007) The dual nature of parks: attitudes of neighbouring communities towards Kruger National Park, South Africa. Environmental Conservation, 34, 236-245.

Baral, N. \& Heinen, J.T. (2007) Resources use, conservation attitudes, management intervention and park-people relations in the Western Terai landscape of Nepal. Environmental Conservation, 34, 64 .

Brockington, D. (1999) Conservation, displacement, and livelihoods: the consequences of the eviction for pastoralists moved from the Mkomazi Game Reserve, Tanzania. Nomadic Peoples, 3, 74-96.

Brockington, D. (2002) Fortress Conservation: The Preservation of the Mkomazi Game Reserve, Tanzania. James Curry, Oxford, UK.

Brockington, D. \& Igoe, J. (2006) Eviction for conservation: a global overview. Conservation and Society, 4, 424-470.

Brockington, D., Igoe, J. Schmidt-Soltau, K. (2006) Conservation, human rights, and poverty reduction. Conservation Biology, 20, 250-252.

BROWN, K. (2002) Innovations for conservation and development. The Geographical Journal, 168, 6-17.

Burgess, N.D., Loucks, C., Stolton, S. \& Dudley, N. (2007) The potential of forest reserves for augmenting the protected area network in Africa. Oryx, 41, 151-159.

Büscher, B. \& Wolmer, W. (2007) The politics of engagement between biodiversity conservation and the social sciences. Conservation and Society, 5, 1-21.

Carswell, G. (2007) Cultivating Success in Uganda: Kigezi Farmers \& Colonial Policies. James Currey, Oxford, UK.
Cernea, M. \& Schmidt-Soltau, K. (2003) The end of forcible displacements? Conservation must not impoverish people. Policy Matters, 12, 42-51.

Cernea, M.M. \& Schmidt-Soltau, K. (2006) Poverty risks and national parks: policy issues in conservation and resettlement. World Development, 34, 1808-1830.

Chapman, C.A. \& Lambert, J. (2000) Habitat alteration and the conservation of African primates: a case study of Kibale National Park, Uganda. American Journal of Primatology, 50, 169-186.

Chatty, D. \& Colchester, M. (eds) (2002) Conservation and Mobile Indigenous Peoples: Displacement, Forced Settlement and Sustainable Development. Berghahn Books, New York, USA.

EDMunds, D. (1997) Continuity and change in the resource management institutions of communities bordering the Kibale forest Park, Uganda. PhD thesis, Clark University, Worcester, USA.

Emerton, L. (1999) The Nature of Benefits and the Benefits of Nature: Why Wildlife Conservation has not Economically Benefited Communities in Africa. Institute for Development Policy and Management, University of Manchester, Manchester, UK.

Feeney, P. (1998) Accountable Aid: Local Participation in Major Projects. Oxfam, Oxford, UK.

FiALlO, E.A. \& JACOBSON, S.K. (1995) Local communities and protected areas: attitudes of rural residents towards conservation and Machililla National Park, Ecuador. Environmental Conservation, 22, 241-249.

GADD, M.E. (2005) Conservation outside of parks: attitudes of local people in Laikipia, Kenya. Environmental Conservation, 32, 50-63.

Gillingham, S. \& Lee, P. (1999) The impact of wildlife-related benefits on the conservation attitudes of local people around the Selous Game Reserve, Tanzania. Environmental Conservation, 26, 218-228.

Gillingham, S. \& Lee, P. (2003) People and protected areas: a study of local perceptions of wildlife crop damage conflict in an area bordering the Selous Game Reserve, Tanzania. Oryx, 37, 316-325.

Goldman, A., Harter, J. \& Panikowski, A. (2009) Historic Narrative and Demographic Trajectory Around a Forest Park in East Africa. Paper presented at 2009 Meeting of the Florida Society of Geographers, St Augustine, USA.

Goldman, A., Hartter, J., Southworth, J. \& Binford, M. (2008) The human landscape around the island park: impacts and responses to Kibale National Park. In Science and Conservation in African Forests: The Benefits of Long-term Research (eds R.

Wrangham \& E. Ross), pp. 129-144. Cambridge University Press, Cambridge, UK.

HARTter, J. (2009) Attitudes of rural communities towards wetlands and forest fragments around Kibale National Park, Uganda. Human Dimensions of Wildlife, 14, 433-447.

HARTter, J. (2010) Resource use and ecosystem services in a forest park landscape. Society \& Natural Resources, 23, 207-233.

Hartter, J. \& Goldman, A.C. (2009) Life on the edge: balancing biodiversity conservation and sustaining rural livelihoods. FOCUS on Geography, 52, 11-17.

Hartter, J. \& Southworth, J. (2009) Dwindling resources and fragmentation of landscapes around parks: wetlands and forest fragments around Kibale National Park, Uganda. Landscape Ecology, 24, 643-656.

Hill, C.M. (200o) Conflict of interest between people and baboons: crop raiding in Uganda. International Journal of Primatology, 21, 299-315.

Igoe, J. (2004a) Becoming Indigenous in Africa: The Globalization of Maasai and Barabaig Ethnic Identities. African Studies Working Paper 248. Boston University, Boston, USA. 
I GOE, J. (2004b) Conservation and Globalisation: A Study of National Parks and Indigenous Communities from East Africa to South Dakota. Wadsworth/Thomson Learning, Belmont, USA.

InFIELD, M. (1988) Attitudes of a rural community towards conservation and a local conservation area in Natal, South Africa. Biological Conservation, 45, 21-46.

Infield, M. \& Namara, A. (2001) Community attitudes and behaviour towards conservation: an assessment of a community conservation programme around Lake Mburo National Park, Uganda. Oryx, 35, 48-60.

Kajubu, E. (2008) Kibale park gives Kabarole sh36m. 13th May 2008. The New Vision, Kampala, Uganda.

Kirner, K. (2010) Agricultural variation and change among Batoro and Bakiga farmers around Kibale National Park in south-west Uganda. MA thesis, University of Florida, Gainesville, USA.

Lepp, A. \& Holland, S. (2006) A comparison of attitudes towards state-led conservation and community-based conservation in the village of Bigodi, Uganda. Society \& Natural Resources, 19, 609623 .

Mugisha, A. (2002) Evaluation of community-based conservation approaches: management of protected areas in Uganda. $\mathrm{PhD}$ thesis, University of Florida, Gainesville, USA.

Mulley, B.G. \& UNRUH, J.D. (2004) The role of off-farm employment in tropical forest conservation: labor, migration, and smallholder attitudes toward land in western Uganda. Journal of Environmental Management, 71, 193-205.

Naughton-Treves, L. (1997) Farming the forest edge: vulnerable places and people around Kibale National Park, Uganda. Geographical Review, 87, 27-46.

Naughton-Treves, L. (1998) Predicting patterns of crop damage by wildlife around Kibale National Park, Uganda. Conservation Biology, 12, 156-168.

Naughton-Treves, L. (1999) Whose animals? A history of property rights to wildlife in Toro, western Uganda. Land Degradation \& Development, 10, 311-328.

Neum ann, R.P. (1998) Imposing Wilderness. Struggles over Livelihood and Nature Preservation in Africa. University of California Press, London, UK.

Newmark, W.D., Leonard, N.L., Sariko, H.I. \& Gamassa, D.-G.M. (1993) Conservation attitudes of local people living adjacent to five protected areas in Tanzania. Biological Conservation, 63, 177-183.

Robertson, J. \& Lawes, M.J. (2005) User perceptions of conservation and participatory management of iGxalingenwa forest, South Africa. Environmental Conservation, 32, 64-75.

RoE, D. (2008) The origins and evolution of the conservationpoverty debate: a review of key literature, events, and policy processes. Oryx, 42, 491-503.

Schmidt-Soltau, K. (2003) Conservation-related resettlement in central Africa: environmental and social risks. Development and Change, 34, 525-551.

Schmidt-Soltau, K. (2009) Is the displacement of people from parks only 'purported,' or is it real? Conservation and Society, 7, 46-55.

Shetler, J.B. (2007) Imagining Serengeti: A History of Landscape Memory in Tanzania from Earliest Times to the Present. Ohio University Press, Athens, USA.
Solomon, J. (2007) An evaluation of collaborative resource management and the measurement of illegal resource use in a Ugandan National Park. PhD thesis, University of Florida, Gainesville, USA.

Southworth, J., Hartter, J., Binford, M.W., Goldman, A.C., Chapman, C.A., Chapman, L.J. et al. (2010) Landscape effects of an East African national park on the protected tropical forest and its surrounding area. Tropical Conservation Science, 3, 122-142.

Steinhart, E. (1977) Conflict and Collaboration in the Kingdoms of Western Uganda, 1890-1907. Princeton University Press, Princeton, USA.

Struhsa Ker, T.T. (1997) Ecology of an African Rain Forest: Logging in Kibale and the Conflict Between Conservation and Exploitation. University Press of Florida, Gainesville, USA.

Struhsaker, T.T. (2005) Conservation of red colobus and their habitats. International Journal of Primatology, 26, 525-538.

TERBORGH, J. \& VAN SCHAIK, C. (2002) Why the world needs parks. In Making Parks Work: Strategies for Preserving Tropical Nature (eds J. Terborgh, C. Van Schaik, L. Davenport \& M. Rao), pp. 3-14. Island Press, Washington, DC, USA.

UbOS (Uganda Bureau of Statistics) (2005) The 2002 Uganda Population and Housing Census, Main Report. Uganda Bureau of Statistics, Kampala, Uganda.

UbOS (Uganda Bureau of Statistics) (2009) Visitors to the National Parks (Citizens and Foreigners) 2004-2008. Uganda Bureau of Statistics, Kampala, Uganda.

Van Orsdol, K.G. (1986) Agricultural encroachment in Uganda's Kibale Forest. Oryx, 20, 115-117.

West, P., Igoe, J. \& Brockington, D. (2006) Parks and peoples: the social impact of protected areas. Annual Review of Anthropology, 35, 251-277.

Wittemyer, G., Elsen, P., Bean, W.T., Coleman, A., Burton, O. \& Brashares, J.S. (2008) Accelerated human population growth at protected area edges. Science, 321, 123-126.

Wrangham, R. \& Ross, E. (eds) (2008) Science and Conservation in a Ugandan Forest: How Long-Term Research can Help Habitat Management. Cambridge University Press, Cambridge, UK.

\section{Biographical sketches}

Joel HartTer's research focuses on the social and ecological impacts of landscape change. For the past 5 years he has worked on analysis of land use and land cover change in and around Kibale National Park and on the impacts of, and responses to, the Park by surrounding people and communities. He currently leads a project examining social and ecological change in the rural American West. Aвraham Goldman's research focuses on environmental and agricultural change in sub-Saharan Africa, including field research in Kenya, Nigeria, Uganda and elsewhere. For the past several years he has been working with interdisciplinary research projects focused on the social and environmental impacts of protected areas in East and southern Africa, including work in Uganda, Tanzania, Botswana and Namibia. 